\title{
Physical Fitness of Cleaners in Faculty of Medicine Universitas Padjadjaran, November 2012
}

\author{
Adi Wibisono Sulistijo, ${ }^{1}$ Ambrosius Purba, ${ }^{2}$ Tri Damiati Pandji ${ }^{3}$ \\ ${ }^{1}$ Faculty of Medicine Universitas Padjadjaran, ${ }^{2}$ Department of Physiology Faculty of Medicine, \\ Universitas Padjadjaran, ${ }^{3}$ Department of Physical Medicine and Rehabilitation, Faculty of \\ Medicine Universitas Padjadjaran/Dr. Hasan Sadikin General Hospital Bandung
}

\begin{abstract}
Background: Cleaning is an occupation that is carried out worldwide in many different environments. Cleaning workers (cleaners) often have low occupational skills and belong to the less advantaged educational and socioeconomic groups. Because of the high physical work demands and low cardiorespiratory fitness, cleaners have the risk to have cardiovascular diseases. The aim of this study was to measure the 5 components of physical fitness (cardiorespiratory endurance, muscle endurance, muscle strength, flexibility and body composition) of cleaners in Faculty of Medicine Universitas Padjadjaran.

Methods: A descriptive study was carried out to all cleaners (31 persons) of Faculty of Medicine Universitas Padjadjaran in November 2012. The subjects were tested for cardiorespiratory endurance, muscle endurance, muscle strength, flexibility and body composition. The results were categorized using the standard of Ministry of Health Republic Indonesia.

Results: From 31 subjects, cardiorespiratory endurance was in poor category (50\%). Shoulder and hand muscle endurance was in poor category (54.8\%) and stomach muscle endurance was in very poor category (67.7\%). Hand-grip muscular strength was in very poor category: right hand $(80.7 \%)$ and left hand $(87.1 \%)$. Back muscle strength was in poor category $(58.1 \%)$. Leg muscular strength was in very poor category (48.4\%). Flexibility was in a very good category (97\%) and body composition was also in a good category (54.8\%).

Conclusions: From 5 components of cleaners' physical fitness, 3 components (cardiorespiratory endurance, muscle endurance and muscular strength) are in poor and very poor category. [AMJ.2015;2(3):382-86]
\end{abstract}

Keywords: Cleaners, occupational health, physical fitness.

\section{Introduction}

Mens sana In Corpore Sano, "inside a healthy body resides a healthy mind". This famous quote is similar to the World Health Organization (WHO) definition about health as quoted by the Ministry of Health of the Republic of Indonesia, health is a state of complete physical, mental and social wellbeing and not merely the absence of disease or infirmity. ${ }^{1,2}$

Healthy body is essential in human life. There are many advantages in having a healthy body. For example, people will become more resistant to disease and less likely to get degenerative disease such as diabetes, stroke and hypertension at old age. Other benefits by having healthy body or become physically fit are people become more productive in work and less likely to be absent from work.

Cleaning is an occupation that is carried out worldwide in many different environments. It can be done both indoors and outdoors. 3 Cleaning workers (cleaners) often have low occupational skills and belong to the less advantaged educational and socioeconomic groups.3 Because of the high physical work demands and low cardiorespiratory fitness, cleaners have the risk to have cardiovascular diseases. ${ }^{4}$

Dailytask of cleaners in Faculty of Medicine Universitas Padjadjaran are: cleaning the

Correspondence: Adi Wibisono Sulistijo, Faculty of Medicine, Universitas Padjadjaran, Jalan Raya Bandung-Sumedang Km.21, Jatinangor, Sumedang, Indonesia, Phone: +6281312516197 Email: adi.wibisono.sulistijo@gmail.com 
building, taking care of the gardens, picking up trash and put it in dump. Cleaners walk about 100 meters everyday andcarry the trash bins from the buildings to the location of the dump. These activities probably affect the cardiorespiratory endurance (VO2 Max), muscle endurance and strength. In order to be able to do these tasks, cleaners need good physical fitness.

The aim of this study was to measure the 5 components of physical fitness 5,6 (cardiorespiratory endurance, muscle endurance, muscle strength, flexibility and body composition) among cleaners in the Faculty of Medicine Universitas Padjadjaran.

\section{Methods}

A descriptive study was carried out to all cleaners (31 persons), of the Faculty of Medicine, Universitas Padjadjaran for 2 days, $8^{\text {th }}$ and $11^{\text {th }}$ November 2012 . The subjects were tested for cardiorespiratory endurance, muscle endurance, muscle strength, flexibility and body composition.

Cardiorespiratory endurance was measured using Rhyming step-up test. ${ }^{5}$ The subject stood in front of a rhyming chair and wore polar bracelet to assess heartbeat. The heartbeat of the subject before testing must be below 100 beat per minute (bpm). A metronome was set as a tempo for the subject to step up and down on the chair. At the researcher's command, the subject put one leg on the chair and by using the metronome as the tempo, the subject continue to step up and down on the chair. The duration of the test was 5 minutes, after 5 minutes the subject was then allowed to take a rest. After 15 seconds rest, the bpm was collected. The result was then recorded into the Astrand normogram to gain the VO2 max result.

The muscle endurance test was divided into 2 categories: hand shoulder muscle endurance and abdominal muscle endurance. Hand shoulder muscle endurance was assessed by doing push-up test in one minute duration. ${ }^{5}$ Abdominal muscle endurance was assessed by doing sit up test in one minute duration. The results of both tests were the total frequency of sit-ups and push-ups in one minute.

The muscle strength test was divided into several components, those were: hand grip muscle strength test, back muscle strength test and leg strength test. ${ }^{5}$ The procedure to test hand grip muscle strength: the subject stands up while holding the hand dynamometer. The subject than squeezed the hand dynamometer as hard as he can. The force resulted from squeezing the dynamometer would move the pointer in the scale. The number that was shown by the pointer was then recorded. To assess the back muscle strength, the subject stood on the back-leg dynamometer. The subject then lean forward while holding the handle with both arms (right hand in pronation position, left hand in supination position) at the height of thigh. The subject then pulled as hard as he could. The number that was shown in the dynamometer was recorded. The procedure for leg muscle strength test the subject stood on the back-leg dynamometer while bending his knee 130-1400. The subject held the handle with both arms and then pulled it as hard as he could. After that the number that was shown in the dynamometer was recorded. All the test was repeated 3 times. $^{7}$

Flexibility was assessed by using sit and reach test method. ${ }^{7}$ The subject sat in front of the Scaling board $(60 \times 20 \mathrm{~cm})$ with both legs in full extension position and both feet touched the board. The back of the subject's knees also touched the floor (knee extensiton). The subject leaned forward while pushing the plate as far as he could by using his fingertips. The number that was shown by the plate was recorded. This test was repeated twice.?

Body composition was measured using skin fat-fold caliper. The location of assessment was on triceps and subscapula. ${ }^{5}$ The procedure assesses the skin fat-fold in triceps: first the researcher pinched the skin in the middle of an

Table 1 Distribution of Cardiorespiratory Endurance

\begin{tabular}{|c|c|c|}
\hline Category & Frequency $(\mathrm{N})$ & Percentage (\%) \\
\hline Very Poor & 7 & 23.3 \\
\hline Poor & 15 & 50.0 \\
\hline Average & 6 & 20.0 \\
\hline Good & 2 & 6.7 \\
\hline Very Good & 0 & 0.0 \\
\hline
\end{tabular}


Table 2 Distribution of Muscle Endurance

\begin{tabular}{lcccc}
\hline \multirow{2}{*}{ Category } & \multicolumn{2}{c}{$\begin{array}{c}\text { Hand and shoulder muscle } \\
\text { endurance }\end{array}$} & \multicolumn{2}{c}{ Abdominal muscle endurance } \\
\cline { 2 - 5 } & Frequency (N) & Percentage (\%) & Frequency (N) & Percentage (\%) \\
\hline Very Poor & 6 & 19.4 & 21 & 67.7 \\
Poor & 17 & 54.8 & 6 & 19.4 \\
Average & 5 & 16.1 & 1 & 3.2 \\
Good & 2 & 6.5 & 1 & 3.2 \\
Very Good & 1 & 3.2 & 2 & 6.5 \\
\hline
\end{tabular}

Table 3 Distribution of Muscle Strength

\begin{tabular}{|c|c|c|c|c|}
\hline \multirow{3}{*}{ Category } & \multicolumn{2}{|c|}{ Hand Grip } & \multirow{2}{*}{$\begin{array}{c}\text { Back Muscle } \\
\text { Strength }\end{array}$} & \multirow{2}{*}{ Leg Strength } \\
\hline & Right & Left & & \\
\hline & $\mathrm{N}(\%)$ & $\mathrm{N}(\%)$ & $\mathrm{N}(\%)$ & $\mathrm{N}(\%)$ \\
\hline Very Poor & $25(80.7)$ & $27(87.1)$ & $10(32.3)$ & $15(48.4)$ \\
\hline Poor & $3(9.7)$ & $0(0.0)$ & $18(58.1)$ & $7(22.6)$ \\
\hline Average & $3(9.7)$ & $4(12.9)$ & $3(9.7)$ & $7(22.6)$ \\
\hline Good & $0(0.0)$ & $0(0.0)$ & $0(0.0)$ & $1(3.2)$ \\
\hline Very Good & $0(0.0)$ & $0(0.0)$ & $0(0.0)$ & $1(3.2)$ \\
\hline
\end{tabular}

imaginary line between coracodeus processus and olecranon while the subject maintained hand in relaxation position (beside body). Pinching was performed by using the thumb and index finger and then, the number shown on the scale was recorded. This test was done 3 times. $^{7}$ The procedure to assess subscapula skin fat-fold: the researcher pinched the skin directly under the lateral left subscapula while the subject maintained standing position. The number shown on the scale was recorded. This test was repeated 3 times. $^{7}$

Afterward, the result of the tests were input into specific gravity formula (Specific Gravity $=1.0909-(0.00101 \mathrm{x}$ triceps +0.0009 $\mathrm{x}$ subscapula)). ${ }^{7}$ Then, the specific gravity was input into body fat percentage formula (Body Fat Percentage $=(5.548 \div$ sp.gr -5.044$) \mathrm{x}$

\section{$100 \%)^{7}$}

The results of the measurement of 5 components of physical fitness were categorized using the standard in the Ministry of Health of the Republic of Indonesia.

\section{Results}

The result of the cardiorespiratory endurance test showed that $50 \%$ of subjects had poor cardiorespiratory (Table 1).

As for the other physical fitness component, muscle endurance test was divided into hand and muscle endurance, and abdominal endurance. Hand and shoulder muscle endurance is mostly poor (54.8\%) while abdominal muscle endurance shows mostly in

Table 4 Distribution of Flexibility

\begin{tabular}{|c|c|c|}
\hline Category & Frequency (N) & Percentage $(\%)$ \\
\hline Very Poor & 0 & 0.0 \\
\hline Poor & 0 & 0.0 \\
\hline Average & 0 & 0.0 \\
\hline Good & 1 & 3.2 \\
\hline Very Good & 30 & 96.8 \\
\hline
\end{tabular}


Table 5 Distribution of Body Fat Percentage

\begin{tabular}{|c|c|c|}
\hline Category & Frequency (N) & Percentage (\%) \\
\hline Poor & 0 & 0.0 \\
\hline Very Good & 2 & 22.6 \\
\hline Good & 17 & 54.8 \\
\hline Average & 7 & 6.5 \\
\hline Over & 0 & 0.0 \\
\hline Fat & 4 & 12.9 \\
\hline
\end{tabular}

very poor category $(67.7 \%)$ (Table 2 ).

The muscle strength test was divided into: hand grip strength, back muscle strength and leg strength. The result of hand grip strength test in Table 3 shows that almost all subjects were in very poor category (right hand $=80.7 \%$; left hand=87.1\%). Back muscle strength result was mostly dominated in poor category (58.1\%) while majority of leg strength test result was in very poor category $(48.4 \%)$.

The result of flexibility test was almost every subject had a very good test result $(96.8 \%)$ (Table 4). As for body fat percentage, the result in table 5 shows that most of the subjects had good result (17\%).

\section{Discussions}

The physical fitness overviews of cleaners in the Faculty of Medicine Universitas Padjadjaran were poor. This was based on the result of cardiorespiratory endurance test that was dominated by poor category (50\%) and very poor category (23.3\%). Many cleaners rarely did exercise. This statement was based on the interview with coordinator of the cleaners.

A study by Bonaiuto et $\mathrm{al}^{8}$, discovered that there was a positive relation between intense physical aerobic-anaerobic activity on cardiovascular autonomic system adjustments. A good cardiovascular autonomic system adjustment means a better cardiorespiratory endurance under physical stress. A good cardiorespiratory endurance can maximize the oxygen distribution, by increasing production of Adenosin Triphosphate (ATP) and Creatinine phosphate as the source of energy and increasing people tolerance towards lactic acid and delaying tiredness. ${ }^{9,10}$

Moreover, the results of cleaner's muscle endurance and muscle strength were poor and very poor. This could happen as the result of sedentary lifestyle or limited physical activity of the subjects so the muscle cells became untrained and easily become fatigued. ${ }^{9,10}$

On the other hand, flexibility and body fat percentage shows a remarkable result. The subjects had very good flexibility because the activity as cleaning service included many bending activities in order to clean difficult places. As the result, the tendon attached to the joint became more flexible and increased the joints Range of Movement (ROM).6 Body fat Percentage describes how much fat was deposited in the whole body. Body fat deposition depends on the balance between energy intake and energy output. Most of the subjects had very good and good body fat percentage category, which means that there was an equilibrium between energy intake and energy expenditure. ${ }^{11}$

Identification of factors that influence the cleaners' poor physical fitness and comparison of the physical fitness with other occupational groups were not carried out, were the limitation of this study.

It can be concluded that the physical fitness of the cleaners in Faculty of Medicine Universitas Padjadjaran were poor, and there are some recommendations in order to increase the physical fitness. To increase the capability of cardiorespiratory endurance, cleaning service workers should do physical activity continuously around 60 minutes which is performed 3-5 times a week with sub maximal intensity. ${ }^{7,8}$ To increase muscle endurance and strength, the cleaners collect the garbage in one big garbage plastic and increase the weight of garbage from time to time before putting it in the dump. To maintain the flexibility, cleaning service workers are recommended to do stretching before starting to work.

\section{References}

1. World Health Organization. Constitution 
of the World Health organization. World Health Organization. 2006 [Cited 2012 September 10]. Available from: http:// www.who.int/about/definition/en/print. html.

2. Ministry of Health republic Indonesia. Constitution of Health Republic Indonesia Year 2009. Ministry of Health republic Indonesia. 2009 [Cited 2012 September 10]; Available from: http://www.pppl. depkes.go.id/_asset/_regulasi/UU_36_ Tahun_2009[1].pdf

3. Zock JP. World at work: cleaners. Occup Environ Med. 2005;62:581-4

4. Korshøj M, Krustrup P, Jørgensen MB, Prescott E, Hansen AM, Kristiansen J, et al. Cardiorespiratory fitness, cardiovascular workload and risk factors among cleaners; a cluster randomized worksite intervention. BMC Public Health. 2012;12:645

5. Caspersen CJ, Powell KE, Christenson GM. Physical activity, exercise and physical fitness: definition and distinctions for health-related research. Public Health Rep. 1985;100(2):126-31.
6. Harsono. Coaching dan aspek-aspek psikologis dalam coaching. Jakarta: CV Tambak Kusuma; 1988

7. Universitas Padjadjaran, Ministry of Health Republic Indonesia. Modul pelatihan kesehatan olahraga di Balai Kesehatan Olahraga Masyarakat (BKOM). Bandung: Ministry of Health Republic Indonesia West Java. 2003.

8. Bonaiuto M, Di Mauro D, Speciale F, Pagano F, Buda D, Vita G, Magaudda L, Trimarchi F. Evaluation of heart rate recovery in relation to playing position in professional soccer player. J Sports Med Phys Fitness. 2012; 52(6):583-8.

9. Guyton AC. Textbook of medical physiology. 11th Ed. Pensylvania: Elsevier Saunders; 2006.

10. Purba A. Fisiologi kedokteran: kardiovaskular dan faal olahraga. Bandung: Department of Physiology, Faculty of Medicine, Universitas Padjadjaran; 2012.

11. Whitney E, Rolfes SR. Understanding nutrition. 10 ${ }^{\text {th }}$ Ed. Belmont: Thomson Wadsworth; 2005 